\title{
Customer-Oriented Public Service in Township Administration: Enabling Quick Response
}

\author{
HuI-Fun Yu, KuO-YAN WANG \& CHUN-YING SHEN
}

\begin{abstract}
The quality reliability and maintenance of a street lighting system are highly related to society, which reflect the administrative performance of a local government. However, the existing published studies seldom discuss the specific civil customer-oriented street lighting system, which is the key factor of both the local administration performance indicators and resident's satisfaction. This study proposes a management conclusion based on an empirical electronic street lighting system (ESLS) and the 280 resident questionnaire surveys in Taiwan. The implication of the existing perspective on management concept is that electronic governance (e-governance) systems emerging in Eastern Europe are going to meet the needs of local governments in terms of the experience level of townships that practice e-governance in Taiwan.
\end{abstract}

KEYWORDS: - electronic governance - e-governance - quick response $\bullet$ township office management $\bullet$ new public management $\bullet$ NPM

CorRespondence AdDress: Hui-Fun Yu, Department of Banking and Finance, Chinese Culture University, 55, Hwa Kang Rd., Yang Ming Shan, Taipei, Taiwan, R.O.C., email: hfyu@cute.edu.tw. Kuo-Yan Wang, Graduate Institute of Management Science, Tamkang University, 151, Ying Jhuan Rd., Danshuei Township, Taipei County, Taiwan, R.O.C. email: philipwang1688@gmail.com. Chun-Ying Shen, Department of Business Administration, Ching Yun University, 229, Jian Sing Rd., Jhongli City, Taoyuan County, Taiwan, R.O.C., email: shency@cyu.edu.tw. 
In the past, the experience of citizens waiting for public services was often timeconsuming and slower than taking on public obligations. Insufficient transparency, inefficiency, and ineffectiveness were often blamed on the whole service procedure. A critical concern was what kind of local government citizens would accept. Therefore, the concept of 'reinventing government' was acquired in the existing public administration (Hambleton, 2000). Many previous studies have emphasised the quality of website design and connectivity (Reichheld et al., 2000a, 2000b.), the influence of democratisation processes (Lowndes and Sullivan, 2004), and the local welfare (Granberg, 2008), which thanks to electronic governance (e-governance), plays an important role in effective promotion of 'reinventing government' (Kieran \& McDonagh, 2006). Deliotte and Capgemini (2008) propose that the two sub-dimensions of e-governance effectiveness should be used to ease the administrative load, and thereby increasing inhabitant satisfaction. These studies only focus on nationwide egovernance development instead of specific administrative work. On the other hand, previous works are more concerned with the level of e-governance policymaking (RDEC, 2003), a conceptual framework (Kumar et al., 2007), and construction of the national information communication technology (ICT) infrastructure (Colesca \& Loliana, 2009). Bélanger and Carter (2008) also mention that civilian usage does not usually generalise the growing annual budget. Whereas Kieran and McDonagh's (2006) study deals with a county authority that undertakes public service modernisation in e-governance, fewer indicate that egovernance requires some administrative measures at the local government level.

In addition, the concept of supply chain management can also be derived in the public service process. Analogously, the role of a public sector is a service totalsolution provider and resident is the customer who has the authority to change the provider during a periodical local selfelection. Past studies indicate that the solution for resolving the tensions between suppliers and consumers is a quick response (Cachon \& Terwiesch, 2009). Krishnan et al. (2010) have ascertained that the upstream manufacturer/supplier considers the downstream retailer/consumer with high inventory a loyal customer. If the upstream product problems increase, the supplier's creditability falls. Hence, in this study, the proposition of the popular vote for township management must be recognised in the downstream retailer/consumer with high weight. The township administration performance indicators are effective tools for improving and achieving the voters' satisfaction.

Furthermore, Andrei et al. (2009) prove that inadequate transparency on the part of the public service provider could cause a series of corruption and malfeasance cases. The improved transparency in administrative operations certainly improves the public image of government. Therefore, in addition to providing citizen/user convenience, this study seeks a method that allows specific public services via 
ICT to bring more information transparency and a quick response to the needs of the rank-and-file.

This paper deals with e-governance at the township level. It specifically indicates the case of implementing the electronic street lighting system (ESLS). Generally speaking, street lighting has important functions in reducing the risk of accidents, especially at night, in protecting property, in discouraging vandalism and crime, as well as in ensuring the security of residents. For example, a failed street lamp may endanger public safety, or cause traffic accidents in the region. Undoubtedly, a quick response to the failed street lights is worthwhile administrative work. This study shows surveys conducted among the residents of numerous representative townships that were using ESLS for a specific period of time. The paper also determines the results that can provide reference values for the countries developing local high-quality e-governance initiatives.

\section{$2 \quad$ Methodology}

\subsection{Sampling}

The survey areas cover three townships in Taiwan where ESLS has been employed for more than four years. In an attempt to explore the impact of using an e-service, e.g., ESLS, the survey respondents were town residents. Each questionnaire item on a 5-point Likert scale, and option descriptions depended on dimensions. The survey period was from 1 March 2010 to 30 June 2010, and 390 questionnaires were issued. For precise measurements, this survey excluded invalid questionnaires as well as interviewees who were unwilling to answer. Thus, 280 valid interviews (approximately 72\%) were conducted in person.

\subsection{Variable Selection}

In order to measure the value of services in towns that used ESLS, this paper classified service content dimensions (Ruiz et al. 2007) as follows: service quality, service equity, confidence benefits, perceived sacrifice, service value, customer satisfaction, and repurchase intentions. Portions of the study dimensions derived from the last 'repurchase intentions' were interesting in that they provided a certain interpretation of the extent of town resident support for incumbent town management

\section{$3 \quad$ Result}

Table 1 shows town resident opinions on service content in the towns that use ESLS. In this study, the KMO value is 0.76 , and the Barlett test is significant $(p<0.001)$. In the service quality dimension, the interviewees are either generally satisfied with ELMS implementation (35\%) or 'extremely satisfied' with ELMS (18.9\%). In service equity, $42.3 \%$ of respondents agree that they are being treated fairly when discussing 
the matter of street lamp failures since ESLS has been put into operation. In confidence benefits, $57.8 \%$ of town residents have strong confidence in ESLS service. After being asked whether they had experienced trade-off to get the new-style service, $63.6 \%$ commented that they had not perceived a sacrifice on ESLS. ESLS was regarded as 'worthy' by $37.5 \%$ of residents, and $30.7 \%$ of them regarded it as 'absolutely worthy'. In the customer satisfaction section, most interviewees were extremely satisfied with ESLS (45.7\%). Interestingly, when asked about repurchase intentions, interpreted as 'reconsider incumbent management', many respondents felt that their political organisation would be highly significant in the next term.

Table 1: The results obtained from the questionnaire survey regarding the use of ESLS in towns

\begin{tabular}{lcc}
\hline Sample items & Frequency & Percentage (\%) \\
\hline Service quality & 98 & 35 \\
Satisfied & 53 & 18.9 \\
Extremely satisfied & & \\
Service equity & 120 & 42.3 \\
Upgraded &
\end{tabular}

\section{Confidence benefits}

Having it 162

57.8

Perceived sacrifice

Not much

Service value

Worthy

Extremely worthy

\section{Customer satisfaction}

Extremely satisfied $\quad 128$

Satisfied

Repurchase intentions

Going to repurchase 


\section{Implications}

\subsection{Accretion of the Electronic Concept in the Existing Public Services}

From 1978 to 1988, Taiwan experienced a long authoritarian period. From the end of the 1980s to the beginning of the 1990s, many Black Sea countries were surging to overthrow the oppressive Soviet regime. According to Addison (2009), one of the goals to get rid of the old baggage from authoritarianism is civilian participation. The masses require a rather significant redistribution of social resources, called 'transition justice', of the past elites. In recent years, the rise of ICT has boosted the development of electronic democracy (e-democracy). Therefore, we have a more transparent information flow. Furthermore, it promotes democracy more efficiently. Hence, Jonavicius (2008) states that effective promotion of the concept of democracy is favoured to enhance the harmony of the neighbouring countries. For instance, e-government readiness rankings are continuously progressing due to the increasing number of personal computers (PC), internet hosts, and telecommunication tool holding rates. The changes in vigour of the growing number of internet users are sufficient conditions for implementing e-governance (Şandor, 2005). In the same way, the advancement of ICT facilities is also extremely helpful for a better systematic organisation of egovernance development at the local level (Stoica, 2003).

For illustrative purposes, Taiwan started using the e-government programme in 1997. The initial stage of the e-government programme is strengthening the ICT network infrastructure environment (Wu et al., 2002). The major goal of the egovernment programme is to establish a 'competent' and 'competitive' government (RDEC, 2003). In 2008, after more than 10 years with ICT infrastructure development, Taiwan and Sweden were ranked 9th among the 34 countries and regions in the World e-Government Ranking Survey by the Institute of E-Government at Waseda University, Japan (Obi, 2008).

In practical terms, the township level sector is frequently limited to the unequal distribution of the budget. The township governments formulate fiscal policy regularly under faction (paixi) pressure within the town council. The factions at the town level mostly maintain good relationships with the ruling party due to interactions of interests instead of royalty (Rigger, 1999). In addition to the civil servants recruited through competitive public examinations, faction support includes township employees and town office management. Hence, compared to the superior level, the town-level policy implementation must be more closely related to local needs than faction demands. The subjective and objective conditions of electronic services are just right for township management to pay attention to administration as can be visible to the public (Figure 1). 


\section{Figure 1: Accretion of the electronic concept in the existing public services}

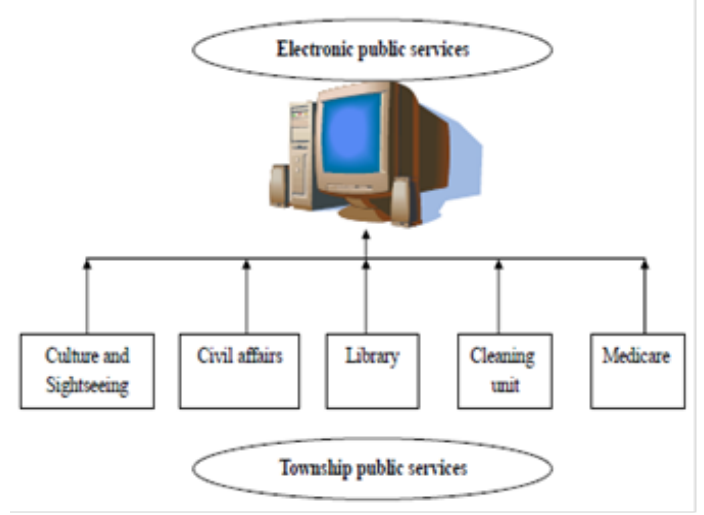

Therefore, the quality of street lighting maintenance systems has spontaneously become a prime issue of public concern. Traditionally, the manual repair operation of a failed street lamp takes about a week. On the other hand, thanks to the ESLS, repair time has shortened from one week to three days. Consequently, in this survey, service value, service quality, confidence benefits, and customer satisfaction are so positively significant that repurchase intensions also have a significant effect. Once town residents are satisfied with the public convenienceoriented services, town management will also improve the degree of its support. Since voter intention is susceptible to various causes, township governance needs to attract their attention with the help of an exhaustive administrative approach.

Through this experience, top-down promotion of e-governance has become an important factor for giving an impetus to e-democracy. The township level is much more closely involved in daily civilian life. The administrative endeavours to upswing local public services in e-governance are going to be more advantageous to the civilian mind.

\subsection{User Satisfaction with Contemporary Governance}

The renaissance of capitalism has affected the new member states of the European Union (EU) in the Black Sea region (i.e., Bulgaria, the Czech Republic, Hungary, Poland, Romania, and Slovenia). In terms of the economic development in these countries, i.e., from centrally planned economies to completely free market economies, there has been much controversy over the process due to the perplexity of the economic and political situation. This drastic change has led to a re-orientation of interactive relationships between government and citizens.

Since the 1980s, many academicians and practitioners have discussed the New Public Management (NPM) theory in order to improve efficiency and performance 
of public sector organisations. A significant example of this is the motivation for ICT employees in e-governance. Public administration improves service delivery to people who are treated as clients, and it encourages citizen participation in government affairs (Pollitt et al. 2007). Thus, an important issue is how to meet the demand of town residents for a variety of public services.

During the martial law period, due to the absence of the checks and balances system, the Taiwanese people simply accepted the public services as they were instead of effectively responding to their quality. After the lifting of martial law, the growing awareness of public service quality (after the democratic trend in the 1980s) meant that the ruling management could disregard neither the voices from the rank-and-file nor the NPM wave in the European public sectors. The Public Construction Commission (PCC) of Executive Yuan in Taiwan introduced the 'Smooth road, lighting lamp, and free-flowing gutter' (lu ping, deng liang, shui gou tong) policy as a basis for assessing the performance of local administration.

Needless to say, township governance is no exception to the rule. On the other hand, the representative assembly of the commission elected by town residents is responsible for supervising township management and administrative procedures. Furthermore, as Figure 2 shows, public opinion is turning into a functional approach to the direct supervision of the government administration.

Figure 2: Supervision procedure and feedback mechanism of public services in township governance

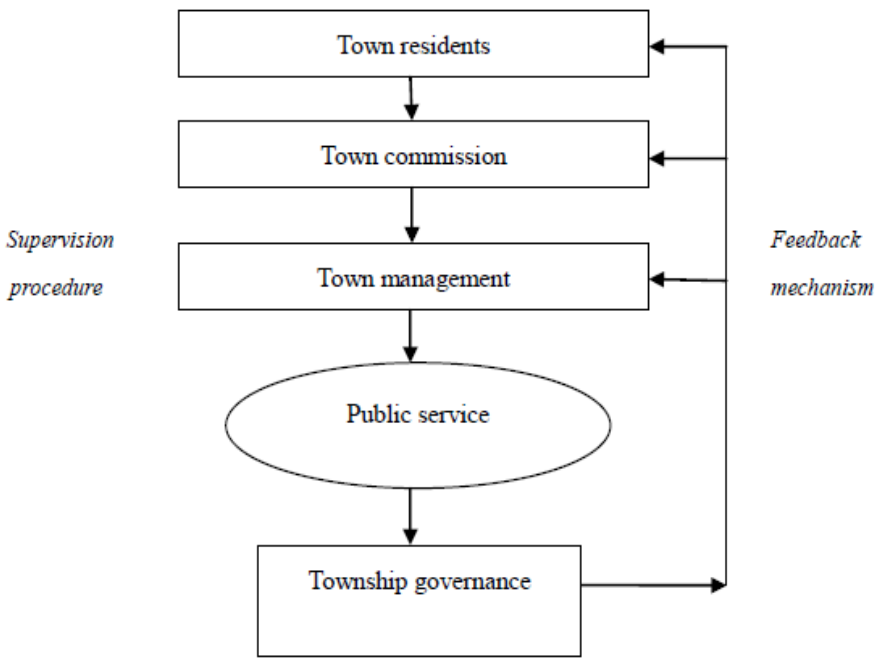

At the same time, residents are satisfied with e-governance of the street light system because ESLS offers a simpler and more transparent method (than the 
traditional manual operational processes do), and governance of a fast response to problems. Successful ESLS operation is not only meet the needs of citizens for public service, and it can also decrease cases of corruption and malfeasance in street lighting maintenance due to high transparency in administrative processes. Besides the fact that the ESLS implementation has shortened the repair period, another fruitful result is that (as an initiative service) the user can check online the status of the failed street lamp repairing process instead of waiting in line for the street lamp failures to be dealt with. There is no doubt that it strengthens the confidence benefits of the town residents' minds. It also coincides with the increased user value and satisfaction.

\section{Conclusion}

This paper outlines a positive impact of ESLS on the town-level government. As part of public services, service quality determines to some extent resident satisfaction. The stakeholders, including town residents and management, recognise the benefits of e-governance implementation. This study confirms that real-time and high-quality public services can really make people raise their degree of satisfaction. Due to the subject limitation, the study only focuses on the effects on the towns that have introduced ESLS. Moreover, the effects of other types of township public services (in terms of electronic assistance) can be discussed in the future.

\section{References}

Addison, T. (2009) The Political Economy of the Transition from Authoritarianism, ICTJ Research Brief (New York: International Centre for Transitional Justice), retrieved from http:// www.ictj.org, 2010/05/17.

Anderi, T., Matei, A., Tuşa, E. \& Nedelcu, M., (2009) Characteristics of the Reforming Process in the Romanian Public Administration System, Transylvanian Review of Administrative Sciences, 23E, pp. 13-31

Bélanger, F., \& Carter, L. (2008) Trust and risk in e-government adoption, Journal of Strategic Information Systems, 17(2), 165-176.

Cachon, G. P., \& Terwiesch, C. (2009) Matching Supply with Demand: An Introduction to Operations Management (New York: McGraw-Hill/Irwin).

Codagnon, C. \& Boccardelli, P. (2006) Measurement Framework Final Version, eGep project for the European Commission, DG Information Society (Brussels: European Union), retrieved from http://82.187.13.175/eGEP/Static/Contents/final/D.2.4_Measur ement_Framework_final_version.pdf, 2010/05/20.

Colesca, S. E. \& Liliana, D. (2009) E-government Adoption in Romania, International Journal of Business, Economics, Finance and Management Sciences, 1(2), pp.1-9.

Deloitte, P.W., \& Capgemini, B. L. (2008) User satisfaction and administrative simplification within the perspective of eGovernment impact: Two faces of the same coin?, European Journal of ePractice, retrieved from www.epractice.eu/files/4.5.pdf, 2010/05/11. 
Lowndes, V. \& Sullivan, H. (2004) Like a horse and carriage or a fish on a bicycle: How well do local partnerships and public participation go together?, Local Government Studies, 30(1), pp. 51-73.

Granberg, M. (2008) Local Governance 'in Swedish“? Globalisation, Local Welfare Government and Beyond, Local Government Studies, 34(3), pp. 363-377.

Hambleton, R. (2000) Modernising Political Management in Local Government, Urban Studies, 37(5-6), pp. 931-950.

Jonavicius, L. (2008) The Democracy Promotion Policies of Central and Eastern European States, working paper (Madrid: Fundación para las Relaciones Internacionales y el Diálogo Exterior (FRIDE)

Kieran, T., \& McDonagh, J. (2006) Electronic Government and Public Service Modernisation: Experience from the Frontline, Proceedings of the Research Forum to Understand Business in Knowledge Society (EBRF), retrieved from http://www.ebrc.fi/kuvat/Kieran_McDonagh_paper.pdf, 2010/04/09.

Krishnan, H., Kapuscinski, R., \& Butz, D. A. (2010) Quick Response and Retailer Effort, Management Science, 56(6), pp. 962-977.

Kumar, V., Mukerji, B., Butt, A. \& Persaud, A. (2007) Factors for Successful eGovernment Adoption: a Conceptual Framework, Electronic Journal of e-Government, $5(1)$, pp. $63-76$.

Obi, T., (2008) The 2008 Waseda University World e-Government Ranking Released (Tokyo: Waseda University), pp. 1-10.

Pollitt, C., van Thiel, S. \& Homberg, V. (2007) New Public Management in Europe (London: Oxford Management Publishing Ltd.).

Research Development and Evaluation Commission (RDEC), (2003) E-Government Development in Taiwan - Providing Innovative Public Services, The Executive Yuan, Taipei, Taiwan, the Republic of China (Taipei: The Executive Yuan).

Reichheld, F. F., Markey, R. G. \& Hopton, C. (2000b.) E-Customer Loyalty - Applying the Traditional Rules of Business for Online Success, European Business Journal, 12(4), pp. 173-179.

Rigger, S. (1999) Politics in Taiwan: Voting for Democracy (New York: Routledge).

Oplotnik, Z. \& Brezovnik, B. (2004) Financing local government in Slovenia, PostCommunist Economies, 16(4), pp. 483-496.

Ruiz, D. M., Gremler, D. D., Washburn, J. H. \& Carrión, G. C. (2008) Service value revisited: Specifying a higher-order, formative measure, Journal of Business Research, 61(12), pp. 1278-1291.

Rau, T. (1994) Betriebswirtschaftslehre für Städte und Gemeinden (München: Verlag Vahlen).

Şandor, S.D. (2005) Digital Divide and e-Government in Romania (New York: The United Nations Public Administration Network), retrieved from http://www.nispa.sk/_portal/files/conferences/2005/papers/200508171100570.Sandor.p df.

Stoica, O. (2003) Shepherding Electronic Sheep? Romania's New Governance, Local Government Brief, Winter 17-18.

Wu, C. W., Shan, H. L., Wang, W. C., Shieh, D. M. \& Chang, M. H. (2002) E-Government Electronic Certification Services in Taiwan (Hsinchu: The Second International Workshop for Asia Pacific Key Infrastructures). 